\title{
SPECIES LIMITS AND CLINAL VARIATION IN A WIDESPREAD HIGH ANDEAN FURNARIID: THE BUFF-BREASTED EARTHCREEPER (UPUCERTHIA VALIDIROSTRIS)
}

\author{
Juan I. Areta ${ }^{1,2,3,4}$ And Mark Pearman ${ }^{2,3,5}$ \\ ${ }^{1}$ Instituto de Bio y Geociencias del Noroeste de Argentina (IBIGEO-CONICET), Museo de Ciencias Naturales de Salta, \\ Mendoza 2, 4400 Salta, Argentina \\ ${ }^{2}$ Grupo FALCO, Calle $117 N^{\circ} 1725$ e/67 y 68, 1900 La Plata, Buenos Aires, Argentina \\ ${ }^{3}$ Aves Argentinas/Asociación Ornitológica del Plata, Matheu 1246/8 (C1249 AAB) Capital Federal, Argentina
}

\begin{abstract}
The Buff-breasted Earthcreeper (Upucerthia validirostris) is endemic to western Argentina, and the Plain-breasted Earthcreeper ( $U$. jelskii, including subspecies saturata in the north and pallida in the south), ranges from northern Peru to northwestern Argentina. They have been considered subspecies, as constituents of a superspecies, and as different species. From north to south, a morphocline, involving an increase of rustiness of the plumage and of $\sim 15 \%$ in bill length, $10 \%$ in wing length, and $20 \%$ in tail length, links jelskii to validirostris. The cline linking jelskii and pallida is gradual, over $\sim 1800 \mathrm{~km}$; that between pallida and validirostris is steep, over $\sim 80 \mathrm{~km}$. The northernmost record of validirostris is from the northern Calchaquies Valley, Salta, northwestern Argentina, a valley surrounded by mountains of up to $\sim 6300 \mathrm{~m}$ above sea level through which the lowest pass is at over $4900 \mathrm{~m}$, forming a barrier between validirostris and the southernmost record of pallida to the north. The song, continuous song, duet, and call of validirostris are structurally indistinguishable from those of jelskii/pallida and from the single available recorded song of saturata. In all playback experiments, validirostris answered by approaching and vocalizing to voices of validirostris and jelskii/pallida and vice versa. Treatment of validirostris as a single species is warranted, and three subspecies can be tentatively recognized: southern validirostris (large, rufescent birds with buff bellies restricted to Argentina), central and northern jelskii (small, pale birds ranging from northwestern Argentina to central Peru), and northern saturata (small, dark, and brownish birds in northern central Peru).
\end{abstract}

Key words: allopatric distribution; Andes; Calchaquies Valley; Furnariidae; jelskii; pallida; playback experiments; saturata; validirostris; vocalizations.

\section{Límites de Especie y Variación Clinal en un Furnárido Altoandino Ampliamente Distribuido: Upucerthia validirostris}

Resumen. Upucerthia validirostris es una especie endémica del oeste de Argentina y U. jelskii, incluyendo las subespecies saturata en el norte y pallida en el sur, se extiende desde el norte de Perú hasta el extremo noroeste de Argentina. Ambos taxa habitan áreas rocosas altoandinas, tienen distribuciones lineales y son parapátricas. Han sido consideradas subespecies de una única especie, propuestas como conformando una superespecie y tratadas como especies diferentes. Aquí demostramos la existencia de una variación clinal en la morfología desde jelskii en el norte a validirostris en el sur, que implica un aumento relativo de $15 \%$ en la longitud de pico, $10 \%$ en la longitud de alas y un $20 \%$ en la longitud de cola, y un incremento en la intensidad de la coloración rufa del plumaje hacia el sur. El salto morfológico entre validirostris y pallida es mucho mayor que la transición gradual entre pallida y jelskii: existe una clina suave que une a jelskii con pallida a lo largo de unos $1800 \mathrm{~km}$, y una clina escalonada entre pallida y validirostris cerca de los $24.5^{\circ} \mathrm{S}$ en unos $80 \mathrm{~km}$. La porción meridional de los Valles Calchaquíes, Salta, noroeste de Argentina, aísla los registros más norteños de validirostris, donde están rodeados por montañas de hasta casi $6300 \mathrm{~m}$ snm mientras que el paso más bajo es de más de $4900 \mathrm{~m} \mathrm{snm}$, constituyendo una barrera que lo separa del registro más austral de pallida un poco más al norte. El canto, canto continuo, dueto y llamado de validirostris fueron estructuralmente indistinguibles de los de jelskii/pallida y de la única grabación de canto disponible de saturata. En todos los experimentos de emisión de cantos previamente grabados, validirostris respondió acercándose y vocalizando a las voces de validirostris y jelskii/pallida, y jelskii/pallida respondió acercándose y vocalizando a las voces de jelskii/pallida y validirostris. Estos datos apoyan su tratamiento como una única especie, donde tres subespecies pueden ser reconocidas tentativamente: validirostris en el sur (aves grandes y rufas con vientres canela restringidas a Argentina), jelskii en el centro y norte (aves pequeñas y pálidas que se distribuyen desde Argentina hasta el oeste de Bolivia, extremo norte de Chile y centro de Perú) y saturata en el norte (aves pequeñas, oscuras y marrones restringidas a una pequeña área del centro-norte de Perú). La subespecie saturata es poco conocida y más estudios son necesarios.

Manuscript received 7 March 2012; accepted 4 August 2012.

${ }^{4}$ E-mail: esporofila@yahoo.com.ar

${ }^{5}$ E-mail: markpearman@speedy.com.ar

The Condor, Vol. 115, Number 1, pages 131-142. ISSN 0010-5422, electronic ISSN 1938-5422. @ 2013 by The Cooper Ornithological Society. All rights reserved. Please direct all requests for permission to photocopy or reproduce article content through the University of California Press's Rights and Permissions website, http://www.ucpressjournals.com/ reprintInfo.asp. DOI: 10.1525/cond.2012.120039 


\section{INTRODUCTION}

Clinal variation may be ubiquitous in nature but difficult to detect. Species with long but narrow linear geographic ranges should be ideal models with which clinality may be evaluated. Clines may be soft, where variation is gradual and evident only over large distances, or steep, where abrupt variation is perceived over relatively short distances. Looking at the extremes or at sufficiently distant points of any cline may overemphasize differences that are diluted when populations interconnected by intermediate phenotypes are studied. This artifact of sampling may have taxonomic consequences if, for example, apparently discrete variants at the end of the cline are considered different species.

The Buff-breasted Earthcreeper (Upucerthia validirostris) is endemic to the Andes and Pampean ranges of western Argentina, and the Plain-breasted Earthcreeper (U. jelskii) ranges from the Andes of northern Peru to extreme northwestern Argentina (Fjeldså and Krabbe 1990). Both taxa inhabit rocky areas high in the Andes, have linear distributions, and are distributed parapatrically, with $U$. validirostris to the south and $U$. jelskii to the north (Figs. 1,2).

The taxonomic rank of these two taxa is controversial (Remsen 2003). Once considered as subspecies of a single species (Hellmayr 1925, Peters 1951), they are currently treated as different species (Meyer de Schauensee 1966, Fjeldså and Krabbe 1990, Ridgely and Tudor 1994, Jaramillo 2003) that form a superspecies (Sibley and Monroe 1990).

Arguing that both species were part of a single morphological cline, Vaurie (1980) considered them components of a single species. This cline comprises larger and more richly colored birds in the south, smaller, paler and drabber birds in the north (Hellmayr 1925, Goodall et al. 1946, Vaurie 1980, Navas and Bó 1987). Alternatively, arguing that there is a marked break in size between northern and southern populations, Ridgely and Tudor (1994) treated them as two different species. Descriptions of their vocalizations do not aid the identification at species level (Fjeldså and Krabbe 1990, Ridgely and Tudor 1994, Mazar Barnett et al. 1998). Areta and Pearman (2009) found their vocalizations to be identical, interpreting this as evidence for merging them in a single species.

Given their habitat preferences, both taxa are likely composed of semi-isolated populations, which should influence their degree of morphological variation. Indeed, three populations now considered to belong within $U$. validirostris have been given formal names (validirostris Burmeister, 1861, rufescens Nores, 1986, and dabbenei Chapman, 1919), and a similar degree of variation resulted in recognition of three subspecies within U. jelskii (jelskii Cabanis, 1874, pallida Taczanowski, 1883, and saturata Carriker, 1933). Despite recent phylogenetic and taxonomic work on the genus Upucerthia (Chesser et al. 2007, Fjeldså et al. 2007), the question lingers as to which treatment is best: are $U$. validirostris and $U$. jelskii two good species, or are they part of a cline in a single species?

In this paper we evaluate the species limits of $U$. validirostris and U. jelskii through a comparison of differences in
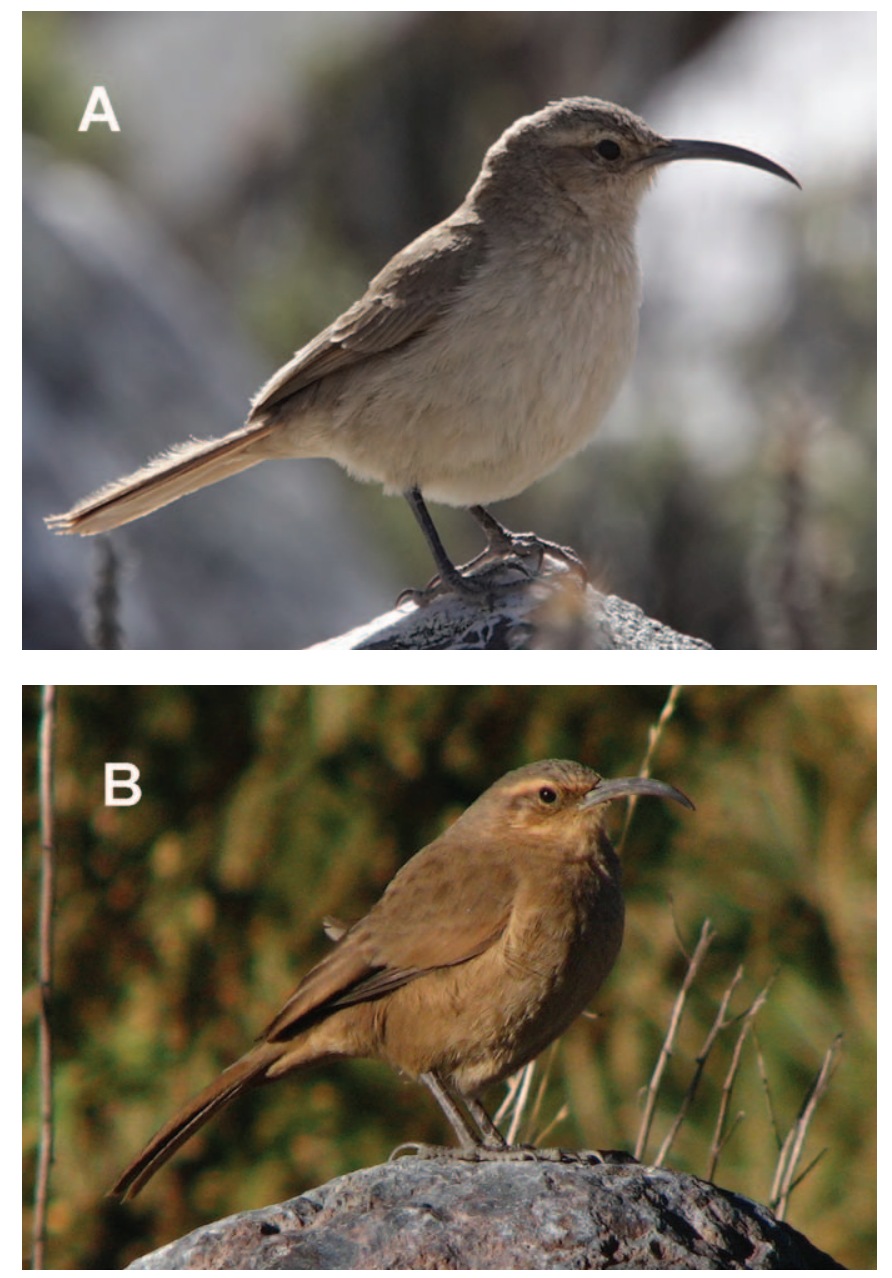

FIGURE 1. A, Adult Plain-breasted Earthcreeper (U. validirostris pallida) photographed at Abra Lizoite, Salta, Argentina. Note the cold brown upperparts and pale breast and supercilium and the shorter, more slender bill. Photo: James Lowen. B, Adult Buffbreasted Earthcreeper (Upucerthia v. validirostris) photographed at El Infiernillo, Tucumán, Argentina. Note the warm brown upperparts, cinnamon-buff breast and supercilium, and the long, strong bill. Photo: Juan I. Areta. These pictures were taken close to the major break in color and size that have resulted in their treatment as separate species. However, they are best treated as geographic variants of a single species.

morphology and vocalizations and evaluation of responses to simulated contact between allopatric populations with the aid of playback. We describe clinal variation across the geographic distribution of the species and evaluate the taxonomic consequences of such a pattern of variation.

\section{METHODS}

\section{MORPHOLOGY}

We measured bill length (exposed culmen) to the nearest $0.1 \mathrm{~mm}$, tail length (base to tip of central pair of rectrices) to the nearest $0.5 \mathrm{~mm}$, and wing length (unflattened wing chord) to the 


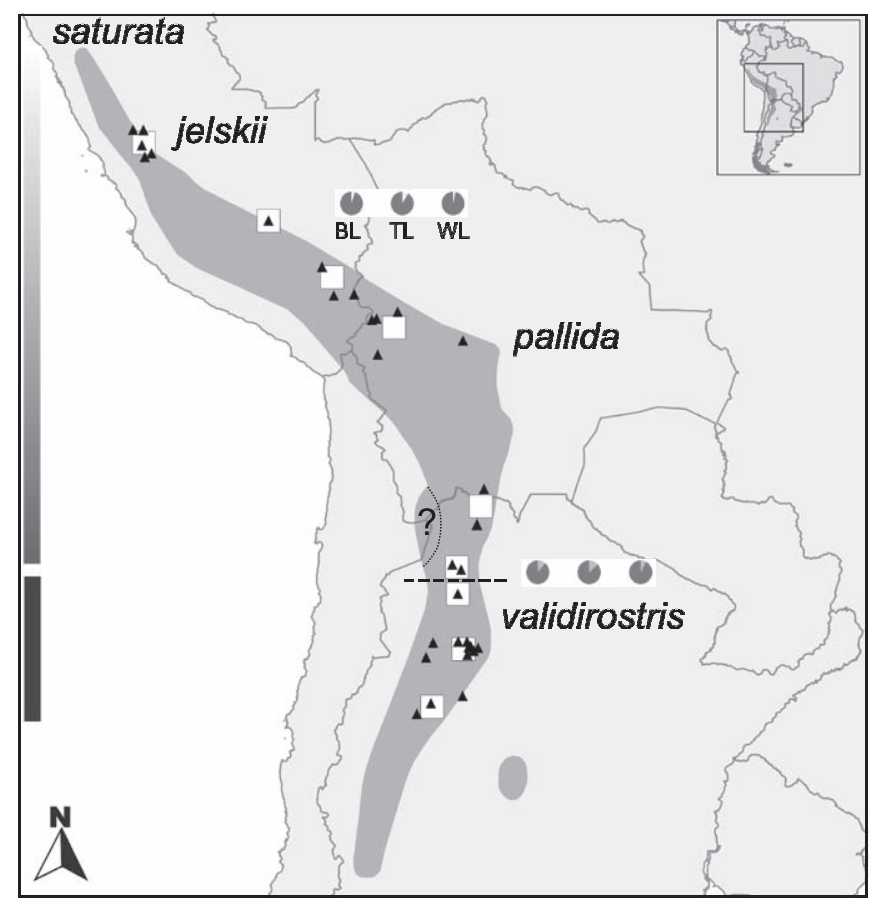

FIGURE 2. Geographic distribution of the Buff-breasted Earthcreeper (Upucerthia validirostris). Frequently recognized taxa vary clinally, with a gradual cline between jelskii and pallida and a steep cline between pallida and validirostris. Black triangles, specimens analyzed by Monmonier's algorithm; white squares, "populations" in this analysis; dashed line, morphological break between jelskii/pallida and validirostris in northwestern Argentina; ?, area without records but mapped as the species' range by Ridgely et al. (2007). Pie charts depict percentage of morphological divergence between jelskii-pallida (less divergent) and pallida-validirostris (more divergent) in bill length (BL), tail length (TL), and wing length (WL). General distribution modified from Ridgely et al. (2007).

nearest $0.5 \mathrm{~mm}$ of 99 museum specimens (55 validirostris, 28 pallida, and 16 jelskii) (Appendix 1, available at http://dx.doi. org/10.1525/cond.2012.120039). We compared the morphological differences in pooled data of all specimens measured by us and by Hellmayr $(1925,1932)$ (Table 1, Appendix 1) with oneway ANOVA and later evaluated differences among taxa with the post-hoc Fisher LSD test, with the level of significance set at 0.05 for all tests. To evaluate clinal variation in measurements, we ran a Spearman correlation analysis between measurements of all specimens and latitude. For all analyses we used StATISTICA. We evaluated geographic variation in the color of museum specimens qualitatively.

To identify natural breaks in morphology across geography, we used Monmonier's maximum-difference method as implemented in the program Barrier 2.2 (Manni et al. 2004; see also Patten and Smith-Patten 2008), which allowed us to estimate the position of boundaries or barriers, i.e., zones where the differences between pairs of populations are largest and which "highlight the geographic areas where a discontinuity exists, meaning that populations, on each side of the barrier, are more similar than populations taken on different sides of the boundary" (Manni and Guérard 2004:20). We calculated averages of bill, tail, and wing lengths and the average geographical position for data grouped by $2^{\circ}$ of latitude, obtaining data for eight " $2^{\circ}$ populations." We calculated Euclidean distances between these populations and built one matrix per trait and another matrix for geographical positions. The initial analysis indicated a consistent barrier to the south of the group at $24-25^{\circ} \mathrm{S}$, but because this " $2^{\circ}$ population" included representatives of both pallida and validirostris, we broke it in two " 10 populations" to obtain a finer resolution of the placement of the barrier and to evaluate its coincidence with taxonomic units. We performed the analysis again with nine "populations" (seven " $2^{\circ}$ " and two "10" populations). This is a conservative estimate of the geographic position of the barrier because reducing the distance between two consecutive populations reduces the chance of a larger morphological leap appearing (i.e., if morphological distance is proportional to geographical distance, reducing the distance in half should also reduce the morphological difference in half).

To evaluate the validity of putative subspecies validirostris, jelskii, and pallida, we calculated the pairwise diagnosability index at $75 \%$ ( $D$-statistic; Patten and Unitt 2002) with the formula: $0 \leq X_{i}-\mathrm{SD}_{i}\left(t_{0.25, \mathrm{df} i}\right)-X_{j}-\mathrm{SD}_{j}\left(t_{0.01, \mathrm{dff} j}\right)$, where $X$ is average, SD is standard deviation and $i>j$. When $D_{i j} \geq 0$ population $i$ is diagnosable from population $j$ and when $D_{i j}<0$ it is not. For two populations to be fully diagnosable (i.e., valid subspecies in this case), the diagnosability must be reciprocal; by swapping $t$ values in the equation above for $D_{i j}$, the complementary equation for $D_{j i}$ is obtained. We calculated $D$ separately for males and females with our data (Table 1).

\section{VOCALIZATIONS}

We recorded the vocalizations of all species of Upucerthia at numerous locations with a combination of Sony TCD5-ProII, Sony TCM-5000, Marantz PMD-222, PMD-660, and PMD661 recorders and Sennheiser ME-62 (in a Telinga Universal parabola), ME-66, and ME-67 microphones (Appendix 1). Recordings made by JIA are deposited in the Macaulay Library of Natural Sounds (MLNS, Cornell Laboratory of Ornithology, Ithaca, NY), those made by MP at the National Sound Archive (NSA, British Museum, London). To determine qualitative differences in the vocalizations of Upucerthia, we examined our recordings aurally and then visually with spectrograms. All spectrograms were produced with Raven Pro 1.4 (Cornell Lab of Ornithology, Bioacoustics Research Program) with the following parameters: overlap 50\%, hop size 128 samples, and Hann window size of 300 samples (150 samples for details of notes in comparisons by species).

To evaluate species limits between validirostris and jelskii, we performed 44 reciprocal playback experiments with voices of both taxa: 13 experiments with validirostris as the subject, 31 with jelskii/pallida as the subject. The design of each experiment was a "sandwich playback" in which we broadcast songs in the order 
TABLE 1. Measurements of bill length, tail length, and wing chord of the Buff-breasted Earthcreeper (Upucerthia validirostris) according to various authors and specimens listed in Appendix 1. Values are given in mm as mean \pm SD with sample size in parentheses and range in brackets. The measurements support the existence of a smooth cline between jelskii and pallida and an abrupt step between neighboring pallida and validirostris and support the treatment of all taxa as part of a single geographically variable species. Note the generally consistent size differences between smaller females and larger males for all taxa with sufficient data.

\begin{tabular}{|c|c|c|c|c|}
\hline Variable and source & validirostris & pallida & jelskii & saturata \\
\hline \multicolumn{5}{|l|}{ Bill length } \\
\hline \multicolumn{5}{|c|}{ Hellmayr $(1925,1932)$} \\
\hline Sexes pooled & $37.1 \pm 1.7$ [34-39] (7) & $33 \pm 2.8[28-38](15)$ & $31.4 \pm 0.9[30-32.5](8)$ & - \\
\hline Males & $37.8 \pm 1.1[36-39](5)$ & $32.6 \pm 3[28-37.5](9)$ & $31.7 \pm 0.8[31-32.5](5)$ & - \\
\hline Females & $35.5 \pm 2.1[34-37](2)$ & $33.6 \pm 2.5[31-38](6)$ & $31.0 \pm 1[30-32](3)$ & - \\
\hline \multicolumn{5}{|l|}{ Esteban (1951) } \\
\hline Males & $39.5[37.1-42]$ & $36.2[32.7-42]$ & - & - \\
\hline Females & $39.7[36.2-44]$ & $37.2[33.7-39.8]$ & - & - \\
\hline \multicolumn{5}{|l|}{ Vaurie (1980) } \\
\hline Females & $38.83[34-41](6)$ & $34.58[31-39](18)$ & $33.78[29-36](9)$ & $33.5[32-35](2)$ \\
\hline \multicolumn{5}{|l|}{ Appendix 1} \\
\hline Sexes pooled & $35.9 \pm 2.5[29.2-41.4](43)$ & $30.6 \pm 2.3[26-36.4](24)$ & $30.7 \pm 1.2[28.7-32.3](12)$ & - \\
\hline Males & $35.4 \pm 2.3[29.2-40.2](19)$ & $31.7 \pm 2.1[29.6-36.4](8)$ & $30.6 \pm 1.5[28.7-32.3](6)$ & - \\
\hline Females & $36.3 \pm 2.9[31.1-41.4](17)$ & $30.1 \pm 2.1[27.1-33.7](13)$ & $30.8 \pm 1[29.2-31.6](5)$ & - \\
\hline \multicolumn{5}{|l|}{ Wing length } \\
\hline \multicolumn{5}{|c|}{ Hellmayr $(1925,1932)$} \\
\hline Sexes pooled & $95.2 \pm 3.2[90-99](7)$ & $87.8 \pm 2[85-91](15)$ & $84.6 \pm 2[81.5-87](8)$ & - \\
\hline Males & $96.5 \pm 2.4[93-99](5)$ & $88.4 \pm 1.9[85-91](9)$ & $85.6 \pm 1.1[84-87](5)$ & - \\
\hline Females & $92.0 \pm 2.8[90-94](2)$ & $86.8 \pm 1.8[85-90](6)$ & $82.8 \pm 1.9[81.5-85](3)$ & - \\
\hline \multicolumn{5}{|l|}{ Esteban (1951) } \\
\hline Males & $92.1[89.6-95.2]$ & $87.2[83.1-91.3]$ & - & - \\
\hline Females & $88.2[85.2-92.3]$ & $86.4[81.5-90.1]$ & - & - \\
\hline \multicolumn{5}{|l|}{ Vaurie (1980) } \\
\hline Females & $92.75[91-97](6)$ & $87.10[83-91](18)$ & $85.2584-87(9)$ & 81.50 [81-82] (2) \\
\hline \multicolumn{5}{|l|}{ Appendix 1} \\
\hline Sexes pooled & $91.2 \pm 3.3[85-100.5](54)$ & $84.7 \pm 2.6[80-89.5](26)$ & $84.0 \pm 2.1[80-87](14)$ & - \\
\hline Males & $92.3 \pm 3.7[87-100.5](23)$ & $85.7 \pm 3.1[80-89.5](9)$ & $84.4 \pm 2.4[80-87](7)$ & - \\
\hline Females & $89.9 \pm 2.3[85-94.5](23)$ & $84.5 \pm 2.3[80-88](14)$ & $83.2 \pm 1.9[80.5-85.5](6)$ & - \\
\hline \multicolumn{5}{|l|}{ Tail length } \\
\hline \multicolumn{5}{|c|}{ Hellmayr $(1925,1932)$} \\
\hline Sexes pooled & $87.1 \pm 3.5[83-91](7)$ & $75.5 \pm 2.7[71-79](15)$ & $68.7 \pm 2.7[65-73](7)$ & - \\
\hline Males & $88.6 \pm 3[84-91](5)$ & $75.9 \pm 2.2[72-78](9)$ & $69.2 \pm 2.6[66-73](5)$ & - \\
\hline Females & $83.5 \pm 0.7[83-84](2)$ & $74.8 \pm 3.4[71-79](6)$ & $67.5 \pm 3.5[65-70](2)$ & - \\
\hline \multicolumn{5}{|l|}{ Esteban (1951) } \\
\hline Males & $83.8[81.4-87]$ & $76.5[70.3-80.2]$ & - & - \\
\hline Females & $80.7[75.7-87.7]$ & $73.9[69.4-78.5]$ & - & - \\
\hline \multicolumn{5}{|l|}{ Vaurie (1980) } \\
\hline Females & $78.84[76-82](6)$ & $69.59[65-78](18)$ & $65.00[62-69](9)$ & $62.25[62-62.5](2)$ \\
\hline \multicolumn{5}{|l|}{ Appendix 1} \\
\hline Sexes pooled & $79.1 \pm 4.4[70.5-89](53)$ & $69.5 \pm 3.3[62.0-75.5](26)$ & $64.9 \pm 2.6[61-69](12)$ & - \\
\hline Males & $79.8 \pm 4.5[70.5-88.5](23)$ & $70.2 \pm 3.8[62-75.5](9)$ & $64.9 \pm 3[61-69](6)$ & - \\
\hline Females & $78 \pm 4.2[71-89](23)$ & $68.8 \pm 3.3[64-74](14)$ & $65.0 \pm 2.6[61.5-67.5](5)$ & - \\
\hline
\end{tabular}


conspecific-heterospecific-conspecific or heterospecific-conspecific-heterospecific, presenting only one of these alternatives to each individual. This design helps in the evaluation of the influence of previous playback on the subject and allows for immediate comparisons with a single subject. We played each song in a sandwich 1-10 times, depending on the response of the bird (playback stopped after response). We noted the subject's behavior in response to playback by the following categories of increasing intensity: no response, approach, vocalization, and approach with vocalization. We avoided pseudoreplication (Kroodsma 1986, 1989a) by choosing different combinations of recordings from our extensive database (Appendix 2, available at http://dx.doi. org/10.1525/cond.2012.120039). Our experiments (numbers in parenthesis) took place at the following localities: validirostris: El Infiernillo, Tucumán, Argentina, each October from 2007 to 2010 (7), June 2009 (4); Cuesta del Obispo, Salta, Argentina, October 2009 (2); jelskii/pallida: Azul Pampa, Jujuy, Argentina, October 2009 (1); between Suripujio and Abra Lizoite, Jujuy, Argentina, October 2009 (1); Abra Lizoite, Salta, Argentina, each October from 2007 to 2010 (5); Putre, Region XV, Chile, October 2005 (1), October 2009 (2), October 2011 (8), January 2009 (1), January 2010 (4); Parque Nacional Lauca, Region XV, Chile, October 2011 (7); Surire, Region XV, Chile, October 2011 (1).

\section{RESULTS}

\section{DISTRIBUTION AND MOVEMENTS}

Three taxa are currently recognized in the jelskii group. The northernmost is saturata, from central northern Peru in Ancash, Huánuco, and northwestern Pasco (Zimmer 1930, Carriker 1933, Remsen 2003). A little farther south, jelskii occupies the Andes of central Peru in Lima, Junín, and Huancavelica (Hellmayr 1925, Koepcke 1970). To the south, wide-ranging pallida extends from Ayacucho, Arequipa, Cuzco, Apurímac, and Puno in southern Peru through western Bolivia in La Paz, Cochabamba, Oruro, and Potosí to northwestern Chile in Arica-Parinacota and Tarapaca and extreme northwestern Argentina in Jujuy and northern Salta (Zotta 1938, Goodall et al. 1946, Johnson 1967, Remsen 2003). These taxa occur from about 3250 to $5000 \mathrm{~m}$ above sea level, possibly higher, in Peru and Bolivia, but down to about $3050 \mathrm{~m}$ in Chile and to $2800 \mathrm{~m}$ in Argentina (Remsen 2003). Two taxa compose the validirostris group. Nominate validirostris is endemic to western Argentina from Salta south through Tucumán, Catamarca, La Rioja, and San Juan to northern Mendoza, ranging from 2400 to $4600 \mathrm{~m}$ above sea level, with an outlying population in the Sierras Grandes of western Córdoba at 1800 to $2200 \mathrm{~m}$ (Leybold 1873, Wetmore 1926, Esteban 1951, Nores et al. 1983). The other taxon, rufescens, occurs only at 2700 to $3200 \mathrm{~m}$ on the semi-isolated Sierra de Famatina, in La Rioja province, northwestern Argentina (Zotta 1938, Nores 1986, Salvador 1992).

Mean altitudes of museum specimens of jelskii $(3780 \pm$ 240 , range $3050-4755, n=16)$ and pallida $(3760 \pm 290$, range
$3000-4280, n=28$ ) did not differ, but they both differed from that of validirostris $(3250 \pm 250$, range $2000-4600, n=54)$. On the basis of observation of groups of 8-10 individuals during winter at $2500 \mathrm{~m}$ at La Ciénaga, Tucumán, Capllonch and Ortiz (2006) and Capllonch et al. (2011) considered validirostris an altitudinal migrant. However, this locality is within the species' regular altitudinal range and at a locality where a specimen has been collected during the breeding season (15 February, Museo de La Plata 423). Moreover, we have found territorial pairs at $2800 \mathrm{~m}$ close to this area during the winter, and subspecies pallida has been considered resident even at high altitudes (e.g., Roe and Rees 1979). Only once have we witnessed downslope movements during a severe snowstorm in Tucumán, Argentina.

The records of pallida nearest validirostris based on museum specimens are $\sim 80 \mathrm{~km}$ away within Salta province, Argentina (pallida: 7 km ESE Abra Blanca, 3800 m, Fundación Miguel Lillo 17018; validirostris: Cachi, 3000 m, American Museum of Natural History 523124). This area's topography varies, but it appears that both forms come into close contact in this region of northwestern Salta, with validirostris seemingly occurring at lower altitude. In reporting a specimen of validirostris from Potosí in Bolivia, Cabot (1990) did not make it clear why the specimen was not pallida (Mazar Barnett and Pearman 2001, Remsen 2003). A second-hand report of a sight record of validirostris in September in the Collón Cura Valley, Neuquén, Argentina (Contreras 1977), lacks a description and would represent a large range extension, we consider it probably erroneous, requiring confirmation.

\section{MORPHOLOGY}

Comparisons of pooled measurements of validirostris, pallida, and jelskii indicated differences among them, in both our dataset (one-way ANOVA, $F_{6,152}=30.85, P=0.00$ ) and that of Hellmayr (one-way ANOVA, $F_{6,48}=13.276, P=0.00$ ) (Table 1). In our dataset, tail lengths of the three taxa differed, while bill length and wing length of validirostris and pallida differed and of validirostris and jelskii differed, but those of pallida and jelskii did not (Fisher LSD test). Results with Hellmayr's dataset were similar, except that pallida and jelskii also differed in wing length (Fisher LSD test). Given the similarities between pallida and jelskii in our dataset, we compared jelskii + pallida against validirostris and found significant differences in all three measures (non-overlapping means $\pm \mathrm{SD}$ ). In all taxa, males were on average larger than females in all measurements (Table 1).

Measurements of bill length, tail length, and wing length in our dataset were correlated positively with latitude, indicating a geographical (clinal) component in morphological variation (Table 1, Figs. 1-3). In these same measurements, however, we found no significant correlation with latitude within each taxon $(-0.14 \leq r \geq 0.26, P>0.05)$, indicating a lack or reduced levels of geographic (clinal) variation within each taxon in our sample. 


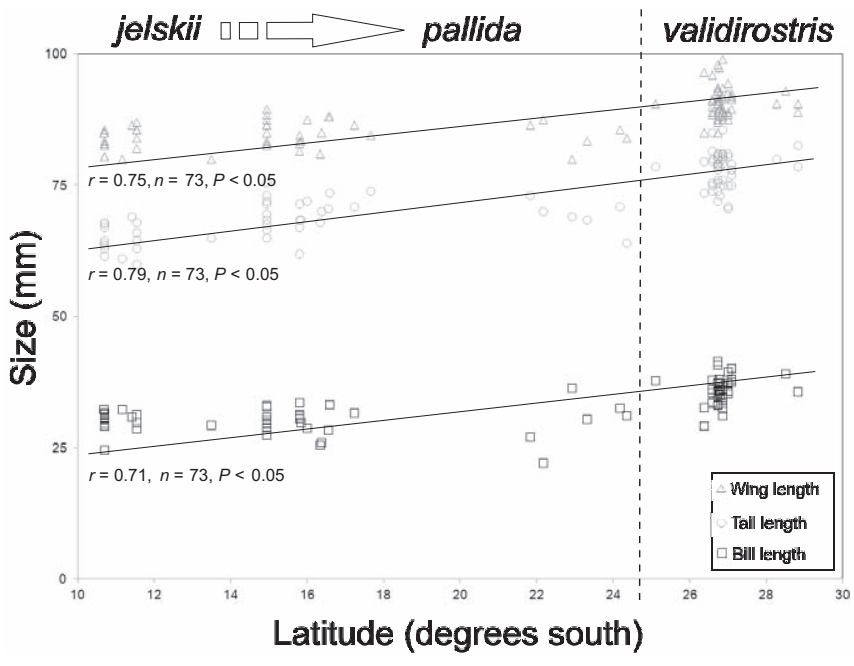

FIGURE 3. Relationship between latitude and morphology in the Buff-breasted Earthcreeper (Upucerthia validirostris). Wing length, tail length, and bill length increase southward. A smooth cline links jelskii and pallida (arrow, see Fig. 2), while an abrupt break separates pallida and validirostris (broken line, see Fig. 2). Data from specimens in Appendix 1.

Analysis of variation of bill, tail, and wing length by Monmonier's algorithm yielded a geographical break (leap) separating validirostris from pallida + jelskii. This first (strongest) barrier appeared consistently between the two " $1{ }^{\circ}$ populations," one being the northernmost specimen of validirostris, the other the southernmost specimens of pallida (Fig. 2).

The cline from northern jelskii to southern validirostris involves an increase of $15 \%$ in bill length, $10 \%$ in wing length, and $20 \%$ in tail length (Table 1). The morphological leap between validirostris and pallida is much greater than the gradual transition between pallida and jelskii. For example, Hellmayr's data show that the leap between validirostris and pallida accounts for $\sim 70 \%$ of the total variation, whereas that between pallida and jelskii accounts for just $\sim 30 \%$ (see Table 1). Geographically, this means that there is a shallow cline linking jelskii and pallida over $\sim 1800 \mathrm{~km}$ and a steep cline between pallida and validirostris close to $24.5^{\circ} \mathrm{S}$ over $\sim 80 \mathrm{~km}$ (Fig. 2). These data support the recognition of two morphological groups: validirostris and jelskii + pallida.

We assessed diagnosability in bill length, tail length, and wing length among validirostris, pallida, and jelskii and between validirostris and jelskii + pallida by the $D$ statistic. Full diagnosability was only achieved between validirostris and jelskii in tail length, in both males $\left(D_{v j}=2.89, D_{j v}=1.48\right)$ and females $\left(D_{v j}=0.14, D_{j v}=0.42\right)$. Interestingly, although validirostris was diagnosable from pallida by bill length $\left(D_{v p}=3.71\right)$, pallida was not diagnosable from validirostris $\left(D_{p v}=-0.72\right)$. We also calculated the $D$ statistic for males in the reduced dataset of Hellmayr (samples of females are extremely small); in this set, full diagnosability was achieved only between validirostris and jelskii but in all three measures, a result obvious from the lack of overlap in all the ranges (Table 1).
Three females of pallida weighed 37, 40, and $41.9 \mathrm{~g}$ (Appendix 1), one male of jelskii $42.5 \mathrm{~g}$ (Appendix 1), and 23 birds of both sexes and subspecies averaged $40.1 \mathrm{~g}$ (Schulenberg 1987). One male validirostris weighed $49.9 \mathrm{~g}$, a breeding female, seemingly weighed with three eggs in the oviduct, $59.3 \mathrm{~g}$ (Navas and Bó 1987), and an unsexed individual $45 \mathrm{~g}$ (Alderete and Capllonch 2010). The mean weight and range Fiora (1933) reported for $U$. v. validirostris, $32.5 \mathrm{~g}$ (30-34.6), on the basis of three birds from Santa Ana, Jujuy, and two from Laguna Colorada (Maimará), Jujuy, are in error because only the smaller pallida occurs at Santa Ana and presumably also at Laguna Colorada. We were unable to track his specimens to corroborate their identification. These scant weight data also demonstrate the similarities in size between jelskii and pallida and a break in size to validirostris.

\section{VOCALIZATIONS}

The song, continuous song, duet, and call of validirostris are structurally indistinguishable from those of jelskii/pallida and from the single available recorded song of saturata (Fig. 4, Appendix 2). The song starts with a few, usually 3-5, lower pitched and softer notes, which increase in intensity and pitch to become a long trill that may end abruptly or slowly decrease in pitch and occasionally in tempo (Fig. 4A, B). The trill is extremely variable in length and number of notes. In the "continuous song" several successive songs are linked by many rapidly delivered notes that gradually change in pitch (Fig. 4C, D). During duetting, a bird (presumably the male) sings the song or long song and the other (presumably the female) utters some harsh notes without any clear rhythm (Fig. 4E, F). These or similar harsh notes can also be emitted by single birds when excited during territorial encounters or in response to playback. The call is a fast and loud treek, which can be transformed into a teek when the first portion of the call is not produced (Fig. 4G, H).

In contrast to the great similarities between validirostris and jelskii/pallida, a comparison of vocalizations among all currently recognized species in the genus Upucerthia shows clear differences in the overall pattern and structure of songs and their constituent repetitive notes (Fig. 5).

Although some previous descriptions of the vocalizations emphasized similarities, others focused on presumed differences. For example, in jelskii "males will sing a long, simple series of rather dry trilled notes from atop a bush or rock," while the behavior of validirostris was similar to that of jelskii, including its "shrill, trilled song" (Ridgely and Tudor 1994: 32); in jelskii "song a rich irregular trill "drrrrrr..." rising and then falling in pitch, accelerating and then decelerating, repeated at short intervals; song of pallida lower-pitched and slower "tuirrrrr," with a few introductory notes and less change in pitch. Call a metallic "click" or "tyi-ik." In validirostris "song a long dry trill of 10 or more "tyik" notes at c. 5 per second; call a low "chwit" (Remsen 2003:247-248). Different individuals and perhaps even the same individual utter sharper or softer versions of the song, including 


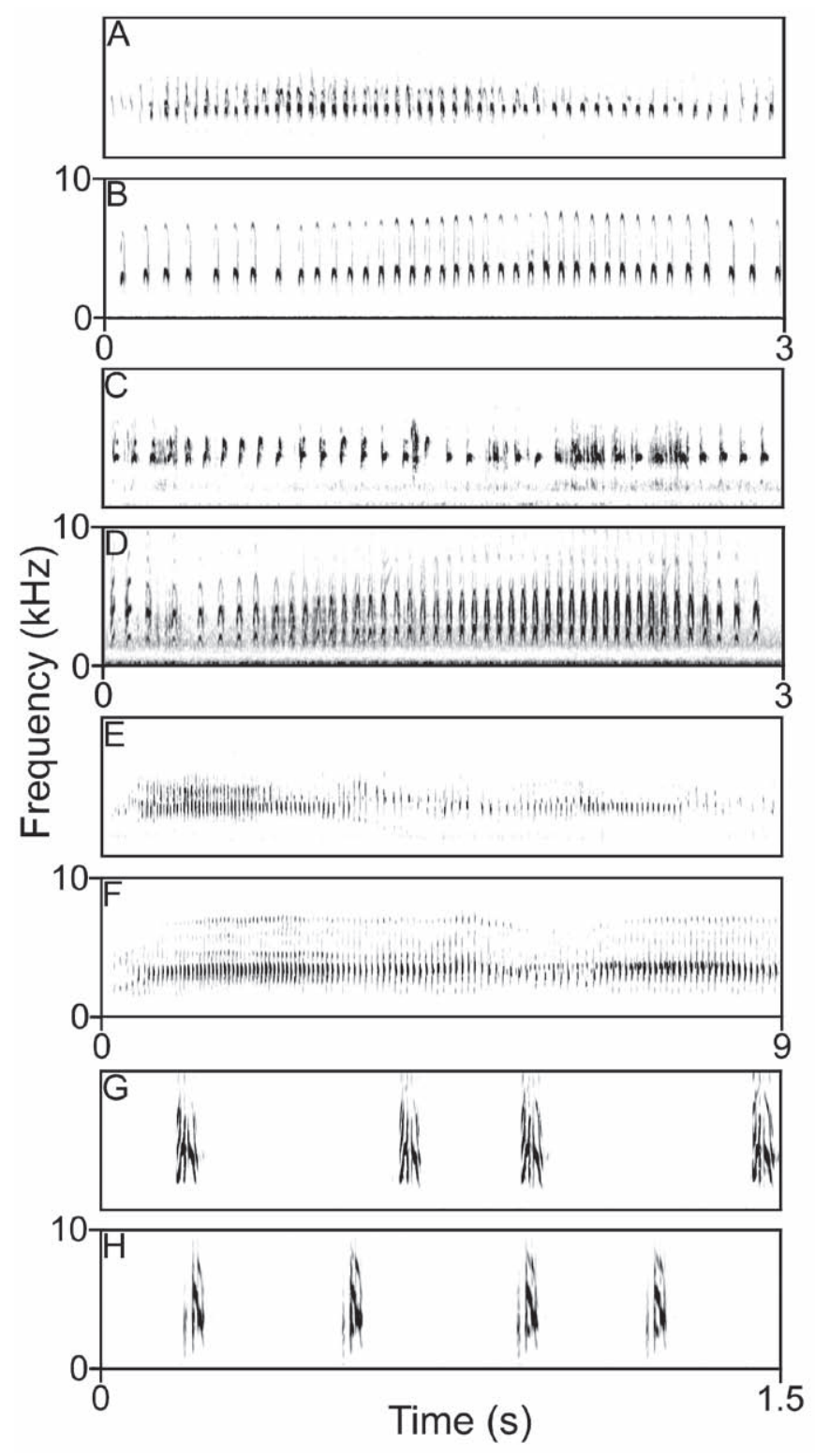

FIGURE 4. Vocalizations of the Buff-breasted Earthcreeper (Upucerthia validirostris), comparing small and pale (jelskii/pallida) vs. large and rufescent (validirostris) individuals. (A) Song of validirostris, El Infiernillo, Tucumán, Argentina; (B) song of jelskii/pallida, Putre, Region XV, Chile; (C) duet of validirostris, El Infiernillo, Tucumán, Argentina; (D) duet of jelskii/pallida, Parque Nacional Lauca, Region $\mathrm{XV}$, chile; (E) continuous song of validirostris, El Infiernillo, Tucumán, Argentina; (F) continuous song of jelskii/pallida, Putre, Region XV, Chile; (G) calls of validirostris, El Infiernillo, Tucumán, Argentina; $(\mathrm{H})$ calls of jelskii/pallida, Putre, Region XV, Chile. All vocalizations of validirostris and jelskii/pallida are very similar, and the response of both groups to playback is indiscriminate; these facts support their merger as a single species. All recordings by JIA.

more rounded or more pointed notes with different quality, at different rates, with or without introductory notes and with different change in pitch, which apparently caused confusion when regarded as species-specific differences (e.g., Fjeldså and Krabbe 1990) and not as individual variation.

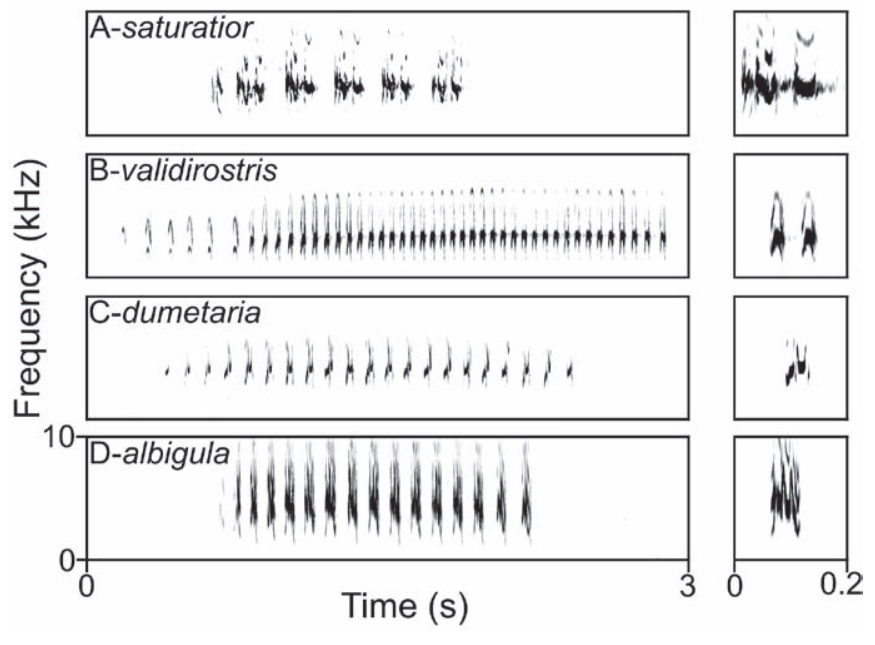

FIGURE 5. Songs (left) and details of repetitive notes (right) of all species of Upucerthia earthcreepers showing differences expected at the species level. (A) Patagonian Forest Earthcreeper ( $U$. saturatior), Paso del Arco, Neuquén, Argentina; (B) Buff-breasted Earthcreeper (U. validirostris), Parque Nacional Lauca, Region XV, Chile; (C) Scale-throated Earthcreeper (U. dumetaria), El Chocón, Río Negro, Argentina; (D) White-throated Earthcreeper (U. albigula), Putre, Region XV, Chile. All recordings by JIA.

In all playback experiments validirostris answered by approaching and vocalizing to voices of validirostris and jelskii/ pallida $(n=13)$, and jelskii/pallida answered by approaching and vocalizing to voices of jelskii/pallida and validirostris $(n=31)$. This is the most extreme result possible (all birds approached and sang in response to playback in all the trials) and indicates that in both validirostris and jelskii/pallida there is no difference in vocal response either to their own or foreign vocalizations. Birds responded strongly to vocalizations both during the breeding season (October and January) and outside of it (June), suggesting year-round territoriality.

\section{DISCUSSION}

\section{TAXONOMY AND SYSTEMATICS}

Our data on morphology, vocalizations, distribution, and behavior indicate that a single biological species is involved, namely, Upucerthia validirostris (Burmeister 1861), including within it the taxa jelskii, pallida, dabbenei, saturata, and rufescens. Upucerthia jelskii, usually considered a separate species, should be considered conspecific with $U$. validirostris; together they form a single biological species in which the degree of clinal variation in morphology differs over its distribution but consistent vocal similarities generate a consistent response to playback throughout its range. Although Remsen (2003) considered pallida vocally distinctive and possibly a species from separate jelskii, our data contradict this idea, since vocalizations of pallida, jelskii, and validirostris are indistinguishable in our sample. This taxonomic treatment would be supported under the biological species 
concept (Mayr 1963) and under the recognition species concept (Paterson 1985).

Voices are thought to be innate in the Furnariidae (Zimmer 2002, 2008, Remsen 2003, Robbins and Zimmer 2005), as in most suboscines (Lanyon 1978, Kroodsma 1984, 1989b, Kroodsma and Konishi 1991). In this family, differences in voices have been repeatedly shown to be species-specific cues of importance to species recognition (Zimmer 2002, 2008, Areta and Pearman 2009, this study). The similarities between the vocalizations of $U$. validirostris and jelskii/pallida and the birds' indiscriminate response to playback of each other's vocalizations provide the strongest evidence for lumping them under a single species. The lack of obvious vocal differentiation between validirostris and jelskii/pallida contrasts with vocal differences of populations of other furnariids that have been considered as different species (Vaurie and Schwartz 1972, Kratter and Parker 1997, Robbins and Zimmer 2005, Areta 2007, Areta and Pearman 2009, Krabbe 2008, Zimmer 2008). The indiscriminate response to playback within this set of taxa contrasts with trials that yielded consistent speciesspecific responses to playback experiments in various Furnariidae (e.g., Zimmer and Whitaker 2000, Zimmer 1997, 2002, 2008, Areta and Pearman 2009).

Clinal variation in vocalizations may or may not exist in the widespread $U$. validirostris, but given the species' long and variable songs and the variation between consecutive songs of the same individual, quantification of vocal characters to investigate such variation would necessitate thorough sampling at the individual, population, and geographic levels. Nevertheless, our simple visual evaluation of vocal similarities between validirostris and jelskii/pallida was corroborated by their consistent behavioral responses to playback.

In the valleys of Putre, northern Chile, and their environs, $U$. albigula coexists with $U$. validirostris pallida without any sign of intergradation (Johnson et al. 1967, Areta and Pearman 2009) and exemplifies species-level differentiation in partly syntopic species. At higher elevations and in drier, flat, or broken areas in the same mountains, only $U$. validirostris pallida is found, whereas only $U$. albigula is known to frequent Polylepis groves. The voices of these two species differ markedly, and in six reciprocal playback experiments that we conducted in October 2011 in Putre, each ignored the vocalizations of the other species and responded strongly to its own, suggesting that there is neither interspecific territoriality nor species-level recognition between them. Two parapatric species, U. saturatior in the Patagonian forests and $U$. dumetaria in open steppe habitats, likewise ignore each other's vocalizations. In our previous work (Areta and Pearman 2009), we were unable to test the response of saturatior to vocalizations of dumetaria while showing that dumetaria ignores the vocalizations of saturatior. We are now able to confirm that saturatior ignores the vocalizations of dumetaria while strongly responding to its own on the basis of three "sandwich" playback experiments at Paso del Arco, Neuquén, Argentina, in December 2011.
Allopatry has traditionally been considered an impediment to the solid evaluation of the species status of such geographically separate populations (Mayr 1963, Remsen 2005). The spatial array of species-level taxa in Upucerthia coupled with their divergence in vocalizations and resulting behavioral data allow us to shed new light on this reasoning. Despite extensive geographic variation in plumage and size, both $U$. dumetaria and $U$. validirostris respond to playback of very distant populations within their wide distributions. The strong response of Upucerthia earthcreepers to vocalizations of distant populations with similar song and their lack of response to vocalizations of nearby, parapatric, or even syntopic populations with dissimilar songs argue strongly that the taxonomic status of allopatric populations can be adequately evaluated with playback experiments. Moreover, in the case of populations separated on isolated mountains, the same situation of allopatry would impede their assignment to the same species under the traditional view, but our studies suggest that this problem can be easily avoided with the aid of playback experiments. In this sense, playback experiments in Upucerthia earthcreepers constitute adequate simulations of syntopy of allopatric populations and of populations isolated by distance.

Although $U$. albigula was confused with $U$. validirostris [pallida] until its description (Hellmayr 1932), it is more closely related to $U$. dumetaria than to any other species (Derryberry et al. 2011). Likewise, U. saturatior was considered a subspecies of $U$. dumetaria even though it is sister to the albigula + dumetaria clade (Areta and Pearman 2009, Derryberry et al. 2011). Finally, the genetic distance between the sister taxa jelskii and validirostris is less than half of that between vocally different Upucerthia species (see Derryberry et al. 2011 for genetic data and Fig. 5 for vocalizations), which further supports their being conspecific. The genus Upucerthia thus consists of four species:

Patagonian Forest Earthcreeper (U. saturatior)

Scale-throated Earthcreeper (U. dumetaria)

White-throated Earthcreeper (U. albigula)

Buff-breasted Earthcreeper (U. validirostris)

\section{ECOMORPHOLOGICAL VARIATION}

Of the four species currently recognized in Upucerthia, two have fairly limited distributions, U. saturatior (Areta and Pearman 2009) and U. albigula (Gast and Gibbons 2010) and exhibit no obvious geographic variation (no subspecies have been recognized within them). The other two, U. dumetaria and $U$. validirostris, are widespread and exhibit clinal variation in size and coloration (several subspecies have been described for both, see Clinal Variation and the Subspecies Problem below).

Our work confirms clinal variation in both coloration and measurements in the validirostris complex, as reported in previous studies (Hellmayr 1925, Esteban 1951, Vaurie 1980). Vaurie (1980: 26-27) summarized variation in plumage as follows: "Birds belonging to nominate validirostris, which 
occupies the southern end of the range of the species, are dull rufous brown above, strongly buffy below with a cinnamon tinge, and have a very extensive rufous area in the wing; but, from south to north, the populations have progressively smaller birds, which are browner above, paler on the underparts (but see below), and in which the size of the rufous area in their wing decreases until the rufous area virtually disappears at the northern extremity of the range of the species in Ancash, Peru. However, the variation is not clinal in all characters because the birds of Ancash (which have been named saturata) are darker below than jelskii from central Peru; and, in the populations (pallida) which intervene geographically between nominate validirostris and jelskii, the tail is slightly more rufous as a rule than in nominate validirostris to the south, becoming brown in jelskii to the north. But, with these exceptions, the variation is clinal in all important respects."

Ecomorphological variation in $U$. dumetaria entails a change from slightly larger and more ferruginous birds in the north (hypoleuca) to, in open areas, smaller and paler birds in the south (dumetaria). Some darker birds occur in wetter areas closer to forests, and darker birds appear randomly in different areas, perhaps because of migration (Areta and Pearman 2009).

Camouflage in relation to habitat humidity has been put forward to account for furnariids' geographical variation in color. Increased pigmentation in relation to habitat humidity has been invoked to explain variation in $U$. dumetaria and other furnariids that inhabit dry and open areas, such as the Common Miner (Geositta cunicularia), Crag Chilia (Chilia [Ochetorhynchus] melanura), Plain-mantled Tit-Spinetail (Leptasthenura aegithaloides), and Cordilleran Canastero (Asthenes modesta) (Hellmayr 1925). With regard to Andean forest ovenbirds, Remsen (1984a: 520) proposed that "in species in which degree of buffy, chestnut, or tawny (= 'rusty') coloration varies geographically, the 'rustiest' form tends to occur at the southern end of the Andes, especially Dpto. Cochabamba, or to a more limited degree at the northern end of the Andes in extreme northern Colombia and Venezuela. Could this increased rustiness be an adaptation for better camouflage because longer dry seasons at the extremes of the Andes make forest there have a 'rustier' appearance?"

The mostly clinal variation in $U$. validirostris, punctuated with abrupt changes in color, may be explained by selection for matching the general coloration of its open rocky habitats, which would be especially important in environments in which predators have good visibility. Both widespread species of Upucerthia apparently fit Gloger's rule (i.e., birds inhabiting more humid regions have darker pigmentation; Remsen 2003); however, the darker individuals of $U$. validirostris do not appear to be more frequent in areas with more rainfall. The existence of the presumably darker form saturata in northern Peru (a humid area) and presumably more rufescent forms in isolated mountains such as rufescens in Famatina (a dry area) suggests that local conditions may influence coloration independently of any general trend and that the general trend arises only because local conditions vary as well. Refined colorimetric analysis of birds and detailed data on rainfall and general coloration of habitats are necessary to test these proposals.

In Bolivia, Traylor (1950) found no significant variation of wing length with altitude within pallida; however, he found that in $83 \%$ of the polytypic species he studied high-altitude subspecies had longer wings than did low-altitude subspecies. Contrary to this trend, specimens of southern $U$. v. validirostris (lower altitude) in our sample averaged longer in wing length than those of northern U.v. jelskii + pallida (higher altitude), suggesting that in this case the latitudinal trend offsets the altitudinal one.

\section{GEOCLIMATIC BARRIERS}

The marked break between validirostris and jelskii/pallida in size and coloration is of biogeographic and evolutionary interest, especially because despite this morphological discontinuity, birds to the north and south of it respond equally strongly to their vocalizations, indicating that they all belong to a single species. Why do some leaps, such as the large change within Salta vs. the smaller change between Salta and southern Peru, involve greater morphological change over a shorter distance than other leaps?

The break in size and coloration in $U$. validirostris coincides with the division between the Calchaquenia (south) and Cordillera Oriental (north) geological provinces, close to the eastern limit of the Puna plateau and convergent with an area of Neogene vulcanism (Salfity 2004, Salfity and Sastre 2009) - a complex geological setting. The northern portion of the Calchaquies Valley encapsulates the northernmost record of validirostris, which is surrounded by mountains of up to $\sim 6300 \mathrm{~m}$ above sea level with the lowest pass at over $4900 \mathrm{~m}$, forming a barrier from the southernmost record of pallida to the north. The uplifting of the eastern and western margins of the Calchaquies Valley was asynchronous: the eastern flank rose first, in the Miocene, and the western margin attained its present altitude during the Diaguita phase of diastrophism in the late Pliocene (Salfity 2004).

Divergence between validirostris and pallida is estimated to have occurred close to the boundary between the middle and lower Pleistocene (see Derryberry et al. 2011). The Puna and the Eastern Cordillera, including both flanks of the Calchaquies Valley, are thought to have reached their current altitude before the separation of pallida from validirostris (Simpson 1979), so orogenesis can be discarded as a cause of their separation. Instead, altitudinal barriers and Pleistocene glaciations may have acted in concert to isolate a widespread population that later broke into jelskii/pallida and validirostris. The highest specimen records of jelskii/pallida (4755 m) and validirostris $(4600 \mathrm{~m})$ in our database are below the lowest pass at the valley head (Abra del Acay, $4959 \mathrm{~m}$ ) where the Calchaquies Valley begins, although both have been reported 
to reach up to $5000 \mathrm{~m}$ in other parts of the species' range (Remsen 2003). During the Pleistocene, the snow line in the central Calchaquies Valley dropped by $900-1000 \mathrm{~m}$ (Hasselton et al. 2002). On the higher peaks of the northern portion of the valley the snow line may have dropped even lower, which would have resulted in an effective east-west barrier isolating birds to the south and north of it in addition to the formidable altitudinal barrier already difficult to overcome. Glaciation on the Puna plateau would have also led toward the separation of these populations (Simpson 1971).

\section{CLINAL VARIATION AND THE SUBSPECIES PROBLEM}

The subspecies category has been the subject of much debate (Patten 2009, 2010, Remsen 2010). Clinal variation is difficult to express nomenclaturally, and this difficulty has been a basis for argument against the use of subspecies (Vaurie 1980, Fitzpatrick 2010). Problems with subspecific designations have permeated the taxonomy of both widespread Upucerthia earthcreepers, $U$. dumetaria and $U$. validirostris.

"The northern subspecies $U$. dumetaria hallinani was synonymized with the more southern $U$. dumetaria hypoleuca on the basis of weak morphological differentiation, local variation in color intensity, and the presence of paler individuals toward drier areas (Hellmayr 1932, Esteban 1951, Johnson 1967)" and "clinal variation, combined with strong individual variation, might have been the basis for Vaurie's (1980) decision to merge all subspecies of dumetaria under nominate dumetaria." (Areta and Pearman 2009: 139). Moreover, the subspecies $U$. dumetaria peruana, described by Zimmer (1954), is known from only two specimens, and its status is uncertain (Areta and Pearman 2009).

The weak morphological diagnosability of the extremes of the cline from validirostris to jelskii (one of three mensural characters) and the lack of such diagnosability between the middle and the extremes (validirostris-pallida, pallidajelskii), argue against recognition of meaningful subspecies on the basis of mensural data. If qualitative color assessments are included, however, the diagnosability of the two subspecies validirostris and jelskii (including pallida) becomes definite, because all individuals can be easily defined as belonging to the rufescent or the pale group. Six formal names at the subspecies level appear to be available for allo/parapatric populations of Upucerthia validirostris: validirostris, rufescens, dabbenei, pallida, jelskii, and saturata. Their subspecific status is yet to be critically evaluated with modern methods (Patten 2010) in light of the clinal variation we report here, but some comments are warranted.

Within jelskii, Bond (1945) recognized all three subspecies. He found nominate jelskii to be "an excellent race, readily distinguishable from pallida" (Bond 1945:24), and considered saturata "a well-marked race, most nearly allied to jelskii, from which it differs at a glance by the grayish brown, rather than buffy, general tone of the underparts; upperparts decidedly darker, with a slight olive tinge; central rectrices dusky brown, not inclining to rufous; under wing-coverts darker cinnamon. The two forms are virtually similar in size" (Bond 1945:25). In contrast, specimens of U. validirostris jelskii "show some approach to pallida, but the differences do not seem to me to be worthy of recognition" (Morrison 1939: 475).

The subspecies jelskii and pallida were described as different species on the basis of specimens from the same type locality (Junín, Peru), but later pallida was used to subspecifically designate birds from the central portion of the range of $U$. validirostris (Cabanis 1874, Taczanowski 1883, Hellmayr 1925). The application of the name pallida is problematic. Hellmayr (1925:45-46) noted, "I am rather doubtful as to the applicability of the name pallida. Taczanowski's description, while corresponding to the birds from southern Peru and Bolivia, was based upon two examples from 'Junín' in the Raimondi collection. All the specimens I have seen from the Junín district are, however, clearly referable to $U$. v. jelskii which is certainly but a northern race of the present bird. I cannot help thinking that there is some mistake about the type locality of U. pallida." As we have shown above, these two subspecies seem to represent points on a gradual cline, and their recognition seems unwarranted (Patten 2010). The subspecies saturata is known from only three specimens presumably diagnosably different in color (Carriker 1933), and until more information is available we recommend its recognition.

In the validirostris group, the description of $U$. validirostris was based on a type specimen from Mendoza (Burmeister 1861). Although Hellmayr (1925) suspected that the type locality was incorrect, more specimens were collected in Mendoza before and after his work, thus dissipating his suspicion (Leybold 1873, Esteban 1951, Navas and Bó 1987).

The name Upucerthia dabbenei refers to birds from the Sierra del Aconquija, Tucumán, Argentina, close to the northern limit of distribution of validirostris sensu stricto (Chapman 1919). However, this "species" has never been recognized in subsequent taxonomic studies because it was treated as a synonym of validirostris at the subspecific level (Hellmayr 1925).

The original description of subspecies rufescens, from the Sierra de Famatina, La Rioja, Argentina, is poor and ambiguous with regard to diagnosable features. The description mentions that "it differs from $U$. v. validirostris by much more marked rufescent underparts. Upperparts are also more rufous and the eyebrow is more cinnamon" (Nores 1986: 265). Four examples of rufescens captured in 1985 and 1986 (two mist-netted and released and two collected) differed from three specimens from 1951 by "being less rufescent in general, more brownish above and more ochraceous below; this indicates that specimens become more rufous with the time. Anyway, the recent specimens from Sierra de Famatina are more cinnamon on the underparts than old specimens of $U$. v. validirostris" (Nores 1986: 265). As there are no biometrical differences and color differences are not clear, we suggest 
that the validity of this taxon requires confirmation. However, Zotta (1938) mentioned that of all the specimens of validirostris he examined, one from La Rioja (Sierra Velasco), which he collected in January 1934, differed notably by its intense coloration. These apparently more rufescent birds sandwiched between northern and southern browner populations do not fit a clinal scheme. If corroborated, these differences imply a leapfrog pattern (Remsen 1984b).

In sum, three subspecies can be tentatively recognized: (1) southern validirostris (large, rufescent birds with buff bellies restricted to Argentina, including validirostris, dabbenei, and rufescens, the last of which may prove to be a distinct subspecies ); (2) central and northern jelskii (small, pale birds ranging from northern Argentina through western Bolivia and extreme northern Chile to central Peru, including jelksii and pallida); and (3) northern saturata (small, dark, and brownish birds restricted to a small area in northern central Peru).

\section{ACKNOWLEDGMENTS}

We thank Ingrid (Mecky) Holzmann, Ted Miller, Alejandro Bodrati, Kristina Cockle, Adriana H. Centeno, Alejandra Grigoli, Richard (Stitch) Johnson, Frank Lambert, James Lowen, Diego Monteleone, Germán Pugnali, and Marcelo Zambrano for sharing field work, and museum personnel for providing access to specimens held in their care. Mecky also provided useful statistical advice. We also thank N. Athanas, T. Bishop, S. Imberti, B. Knapp, N. Krabbe, I. Roesler, and M. Sokol for providing access to their recordings and to recordings held at the Macaulay Library of Natural Sounds and at the National Sound Archive. Fernando Hongn helped with geological data. Philip Unitt provided useful input on specimen foxing. The manuscript benefited from a critical review by J. V. Remsen and an anonymous reviewer. We dedicate this paper to the memory of our friend Juan Mazar Barnett, outstanding person and ornithologist who left this world all too early.

\section{LITERATURE CITED}

Alderete, C., And P. CApllonch. 2010. Pesos de aves suboscines de Argentina. Nótulas Faunísticas 58: 1-12.

AretA, J. I. 2007. Behavior and phylogenetic position of Premnoplex barbtails (Furnariidae). Condor 109:399-407.

Areta, J. I., And M. Pearman. 2009. Natural history, morphology, evolution, and taxonomic status of the earthcreeper Upucerthia saturatior (Furnariidae) from the Patagonian Forests of South America. Condor 111:135-149.

Bond, J. 1945. Notes on Peruvian Furnariidae. Proceedings of the Academy of Natural Sciences of Philadelphia 97: 17-39.

Burmeister, H. 1861. Reise durch die La Plata-Staaten, mit besonderer Rücksicht auf die physische Beschaffenheit und den Culturzustand der argentinischen Republik. Ausgeführt jahren 1857, 1858, 1859 und 1860. 2 volumes. H. W. Schmidt, Halle, Germany. [Spanish translation: G. Burmeister. 2008. Viaje por los estados del Plata. 2 volumes. Dunken, Buenos Aires.]

САВот, J. 1990. First record of Upucerthia validirostris from Bolivia and new Bolivian distribution data. Bulletin of the British Ornithologists' Club 110: 103-107.

CABANIS, J. J. 1874. [Von neuen peruanischen Arten charakterisirt]. Journal für Ornithologie 22: 97-100.

Capllonch, P., AND D. ORTiz. 2006. Los Furnaroides de Tucumán, su hábitat y su distribución. Acta Zoológica Lilloana 50: 85-96.
Capllonch, P., D. Ortiz, And I. Ferro. 2011. Notas sobre la avifauna de las Cumbres Calchaquíes, Tucumán, Argentina. Acta Zoológica Lilloana 55:50-63.

CARriker, M. A. 1933. Descriptions of new birds from Peru with notes on other little-known species. Proceedings of the Academy of Natural Sciences of Philadelphia 85: 1-38.

Chapman, F. 1919. Descriptions of proposed new birds from Peru, Bolivia, Argentina, and Chile. Bulletin of the American Museum of Natural History 41:323-333.

Chesser, R. T., F. K. Barker, And R. T. Brumfield. 2007. Fourfold polyphyly of the genus formerly known as Upucerthia, with notes on the systematics and evolution of the avian subfamily Furnariinae. Molecular Phylogenetics and Evolution 44:1320-1332.

Contreras, J. 1977. La avifauna del valle del río Collón Curá, provincia del Neuquén. Revista IDIA 34:250-270.

Esteban, J. G. 1951. "Furnariinae" de la Republica Argentina. Acta Zoologica Lilloana 12:377-441.

Derryberry, E. P., S. Claramunt, G. Derryberry, R. T. Chesser, J. Cracraft, A. Aleixo, J. Pérez-Emán, J. V. Remsen Jr., And R. T. BRUMFIELD. 2011. Lineage diversification and morphological evolution in a large-scale continental radiation: the neotropical ovenbirds and woodcreepers (Aves: Furnariidae). Evolution 65:2973-2986.

FJeldsA, J., AND N. K. KrabBe. 1990. Birds of the high Andes. Apollo Books, Svendborg, Denmark.

FjeldsÅ, J., M. IREstedt, K. A. Jonsson, J. I. Ohlson, And P. G. P. ERICSON. 2007. Phylogeny of the ovenbird genus Upucerthia: a case of independent adaptations to the terrestrial life. Zoologica Scripta 36:133-141.

FIORA, A. 1933. El peso de las aves. Hornero 5:174-178.

FitZPATRICK, J. W. 2010. Subspecies are for convenience. Ornithological Monographs 67:54-61.

Gast, S. E., AND R. GibBOns. 2010. Range extension for Whitethroated Earthcreeper Upucerthia albigula in Lima, Peru. Cotinga 32:34-36.

GoodAll, J. D., A. W. Johnson, And R. A. PhilipPI. 1946. Las aves de Chile: su conocimiento y sus costumbres, tomo I. Platt Establecimientos Gráficos, Buenos Aires.

Hasselton, K., G. Hilley, and M. R. Strecker. 2002. Average Pleistocene climatic patterns in the southern central Andes: controls on mountain glaciations and paleoclimate implications. Journal of Geology 110:211-226.

Hellmay R, C. E. 1925. Catalogue of birds of the Americas and adjacent islands. Field Museum of Natural History Publications 430, Zoology Series, vol. 13, part IV.

Hellmayr, C. E. 1932. The birds of Chile. Field Museum of Natural History Publications 308, Zoology Series, vol. 19.

Jaramillo, A. 2003. Birds of Chile. Princeton University Press, Princeton, NJ.

Johnson, A. W. 1967. The birds of Chile, vol. 2. Buenos Aires, Platt Establecimientos Gráficos, Buenos Aires.

Koepcke M. 1970. The birds of the Department of Lima, Peru. Livingston, Wynnewood, PA.

KrabBE, N. K. 2008. Vocal evidence for restitution of species rank to a Santa Marta endemic: Automolus rufipectus Bangs (Furnariidae), with comments on its generic affinities. Bulletin of the British Ornithologists' Club 128:219-227.

Kratter, A. W., AND T. A. PARKER III. 1997. Relationship of two bamboo-specialized foliage gleaners: Automolus dorsalis and Anabazenops fuscus (Furnariidae). Ornithological Monographs 48:383-397.

Kroodsma, D. E. 1984. Songs of the Alder Flycatcher (Empidonax alnorum) and Willow Flycatcher (Empidonax traillii) are innate. Auk 101:13-24.

Kroodsma, D. 1986. Design of song playback experiments. Auk 103:640-642. 
Kroodsma, D. 1989a. Suggested experimental designs for song playbacks. Animal Behavior 37:600-609.

Kroodsma, D. E. 1989b. Male Eastern Phoebes (Sayornis phoebe, Tyrannidae, Passeriformes) fail to imitate songs. Journal of Comparative Psychology 103:227-232.

Kroodsma, D. E., AND M. KonISHI. 1991. A suboscine bird (Eastern Phoebe, Sayornis phoebe) develops normal song without auditory feedback. Animal Behavior 42:477-487.

LANYON, W. E. 1978. Revision of the Myiarchus flycatchers. Bulletin of the American Museum of Natural History 161:429-627.

LEYBOLD, F. 1873. Escursión a las pampas arjentinas. Hojas de mi diario. Febrero de 1871. Seguido de tablas de observaciones barométricas, i un boceto de la ruta tomada. Imprenta Nacional, Santiago, Chile.

MANNI, F., AND E. GUÉRARD. 2004. Barrier version 2.2 user's manual. Population genetics team, Musée de l'Homme, Paris.

MANNI, F., E. GuÉRARD, AND E. HeYer. 2004. Geographic patterns of (genetic, morphologic, linguistic) variation: how barriers can be detected by using Monmonier's algorithm. Human Biology 76:173-190.

MAYr, E. 1963. Animal species and evolution. Harvard University Press, Cambridge, MA.

Mazar Barnett, J., And M. Pearman. 2001. Lista comentada de las aves argentinas. Lynx Edicions, Barcelona.

Mazar Barnett, J., R. Clark, A. Bodrati, G. Bodrati, G. PugNali, AND M. Della Seta. 1998. Natural history notes on some little known birds in north-west Argentina. Cotinga 9:64-75.

Meyer de Schauensee, R. 1966. The species of birds of South America with their distribution. Livingston, Narberth, PA.

MorRISON, A. 1939. The birds of the Department of Huancavelica, Peru. Ibis 81: 453-486.

NAVAS, J. R., AND N. A. Bó. 1987. Notas sobre Furnariidae argentinos (Aves, Passeriformes). Revista del Museo Argentino de Ciencias Naturales, Zoología 14: 55-86.

Nores, M., D. Yzurieta, AND R. Miatello. 1983. Lista y distribución de las aves de Córdoba, Argentina. Boletín de la Academia Nacional de Ciencias 56:1-114

Nores, M. 1986. Diez nuevas subspecies de aves provenientes de islas ecológicas argentinas. Hornero 12: 262-273.

Paterson, H. E. H. 1985. The recognition concept of species, p. 21-29. In E. S. Vrba [ED.], Species and speciation. Transvaal Museum Monographs 4.

Patten, M. A. 2009. "Subspecies" and "race" should not be used as synonyms. Nature 457:147.

Patten, M. A. 2010. Null expectations in subspecies diagnosis. Ornithological Monographs 67:35-41.

Patten, M. A., And B. D. Smith-Patten. 2008. Biogeographical boundaries and Monmonier's algorithm: a case study in the northern Neotropics. Journal of Biogeography 35:407-416.

Patten, M. A., AND P. Unitt. 2002. Diagnosability versus mean differences of Sage Sparrow subspecies. Auk 119:26-35.

Peters, J. L. 1951. Check-list of birds of the world, vol. 7. Museum of Comparative Zoology, Cambridge, MA.

REMSEN, J. V. 1984a. Geographic variation, zoogeography, and possible rapid evolution in some Cranioleuca spinetails (Furnariidae) of the Andes. Wilson Bulletin 96:515-523.

REMSEN, J. V. 1984b. High incidence of "leapfrog" pattern of geographic variation in Andean birds: implication for the speciation process. Science 224:171-173.

REMSEN, J. V. 2003. Family Furnariidae (ovenbirds), p. 162-357. In J. del Hoyo, A. Elliot, and D. A. Christie [EDS.], Handbook of the birds of the world, vol. 8: broadbills to tapaculos. Lynx Edicions, Barcelona.

Remsen, J. V. 2005. Pattern, process, and rigor meet classification. Auk 122:403-413.

REMSEN, J. V. 2010. Subspecies as a meaningful taxonomic rank in avian classification. Ornithological Monographs 67:62-78.
Ridgely, R. S., AND G. TudoR. 1994. The birds of South America: the suboscine passerines, vol. 2. University of Texas Press, Austin, TX.

Ridgely, R. S., T. F. Allnutt, T. Brooks, D. K. McNicol, D. W. Mehlman, B. E. Young, And J. R. ZooK. 2007. Digital distribution maps of the birds of the Western Hemisphere, version 3.0. NatureServe, Arlington, VA.

RobBIns, M. B., AND K. J. ZIMMER. 2005. Taxonomy, vocalisations and natural history of Philydor dimidiatum (Furnariidae), with comments on the systematics of Syndactyla and Simoxenops. Bulletin of the British Ornithologists Club 125:212-228.

Roe, N. A., And W. E. ReEs. 1979. Notes on the Puna avifauna of Azángaro province, department of Puno, southern Peru. Auk 96:475-482.

SALVADOR, S. 1992. Notas sobre nidificación de aves andinas en la Argentina. Parte II. Hornero 13:242-244.

SAlfity, J. A. 2004. Geología regional del Valle Calchaquí, Argentina. Anales de la Academia Nacional de Ciencias Exactas Físicas y Naturales 56:133-150.

SAlfity, J. A., AND J. E. SASTRE. 2009. La cuenca cuaternaria endorreica de Cachipampa, Calchaquenia, Salta. Revista de la Asociación Geológica Argentina 65:457-467.

SCHUlENBERG, T. S. 1987. Observations on two rare birds, Upucerthia albigula and Conirostrum tamarugense, from the Andes of southwestern Peru. Condor 89:654-658.

Sibley, C. G., AND B. L. Monroe. 1990. Distribution and taxonomy of the birds of the world. Yale University Press, New Haven, CT.

Simpson, B. B. 1971. Pleistocene changes in the fauna and flora of South America. Science 173:771-780.

Simpson, B. B. 1979. Quaternary biogeography of the high montane regions of South America. University of Kansas Museum Natural History Monographs 7:157-188.

TACZANOWSKI, L. 1883. Description des espèces nouvelles de la collection péruvienne de M. le Dr. Raimondi de Lima. Proceedings of the Zoological Society of London, p. 70-72.

TRAYLOR, M. 1950. Altitudinal variation in Bolivian birds. Condor 52: $123-126$

VAURIE, C., AND P. SCHWARTZ. 1972. Morphology and vocalizations of Synallaxis unirufa and Synallaxis castanea (Furnariidae, Aves), with comments on other Synallaxis. American Museum Novitates 2483:1-13.

VAURIE, C. 1980. Taxonomy and geographical distribution of the Furnariidae (Aves, Passeriformes). Bulletin of the American Museum of Natural History 166:1-357.

Wetmore, A. 1926. Observations on the birds of Argentina, Paraguay, Uruguay and Chile. United States National Museum Bulletin 133:1-448.

Zimmer, J. T. 1930. Birds of the Marshall Field Peruvian expedition, 1922-1923. Field Museum of Natural History Publications 282, Zoology Series vol. 17, no. 7.

ZIMMER, J. T. 1954. A new subspecies of Upucerthia dumetaria (Family Furnariidae) from Peru. Proceedings of the Biological Society of Washington 67:189-194.

ZimMer, K. J. 1997. Species limits in Cranioleuca vulpina. Ornithological Monographs 48:849-864.

ZIMMER, K. J. 2002. Species limits in Olive-backed Foliage-gleaners (Automolus: Furnariidae). Wilson Bulletin 114:20-37.

Zimmer, K. J., AND A. Whittaker. 2000. The Rufous Cachalote (Furnariidae: Pseudoseisura) is two species. Condor 102: 409-422.

Zimmer, K. J. 2008. The White-eyed Foliage-gleaner (Furnariidae: Automolus) is two species. Wilson Journal of Ornithology 120:10-25.

ZotTA, A. R. 1938. Nuevas adiciones a la avifauna argentina. Hornero 7:46-64. 